\title{
Practicing Dialectics of Technoscience during the Anthropocene
}

\author{
Hub Zwart ${ }^{1}$ \\ Accepted: 10 December 2020 / Published online: 20 March 2021 \\ (C) The Author(s) 2021
}

\begin{abstract}
This paper develops a dialectical methodology for assessing technoscience during the Anthropocene. How to practice Hegelian dialectics of technoscience today? First of all, dialectics is developed here in close interaction with contemporary technoscientific research endeavours, which are addressed from a position of proximity and from an 'oblique' perspective. Contrary to empirical (sociological or ethnographical) research, the focus is on how basic concepts of life, nature and technology are acted out in practice. Notably, this paper zooms in on a synthetic cell project called BaSyC as a concrete instantiation of converging views of life, nature and technology currently at work in technoscience. While dialectics is used to explore the significance of this project (of this 'experience' in the dialectical sense), the synthetic cell as a case study also allows us to demonstrate the remarkable relevance of dialectics for understanding contemporary research, notably because it incites us to see the synthetic cell project as a concrete exemplification of life under Anthropocenic conditions. Should we assess the synthetic cell as the ultimate realisation of the technoscientific will to control and optimise life, or rather as an effort to bridge the disruptive collision between technoscience and nature, or both?
\end{abstract}

Keywords Philosophy of technoscience $\cdot$ Dialectics $\cdot$ Concrete universal $\cdot$ Synthetic biology $\cdot$ Synthetic cell $\cdot$ Genomics $\cdot$ Oblique perspective $\cdot$ Anthropocene

\section{Introduction: Rethinking the Philosophical Position}

To practice philosophy under current (Anthropocenic) conditions, philosophers should know their proper place and position vis-à-vis other (more empirical) research fields-or faculties, as Kant (1798/2005) phrased it-, such as the exact life sciences and the social sciences. The Anthropocene not only entails a global environmental cataclysm, it also stages a gigantomachia - a tectonic conceptual collision concerning our basic convictions, our "philosophemes": our answers to 'big' perennial questions such as What is being? What is truth? What is technology? What is nature? What is life? In life sciences research,

Hub Zwart

zwart@esphil.eur.nl

1 Dean Erasmus School of Philosophy, Erasmus University Rotterdam, Bayle Building, Room J5-65, Burgemeester Oudlaan 50, 3062 PA Rotterdam, Netherlands 
such answers are seldomly articulated directly and even the questions as such are hardly ever posed. Rather, the basic convictions (or philosophemes) guiding this type of research are acted out in practice, so that questioning them requires prolonged conceptual work from a specific philosophical perspective. Philosophers should self-consciously position themselves in this emerging force field. This is notably a challenge for academic philosophers, practicing philosophy in academic contexts. If, as Kant (1798/2005) convincingly argued, the university is indeed a battle-field where "conflicts between faculties" rage, ${ }^{1}$ how to situate ourselves on the global campus? For example: should we see ourselves primarily as guardians of lost worlds of thought (focussing on author studies and the history of philosophy), or should we rather develop a critical assessment of current developments at other faculties (addressing the basic convictions and ambiguities emerging in contemporary technoscience and governance research)?

My perspective on this issue is doubtlessly skewed by my own "position" (in the literal sense) because for almost two decades (from 2000 onwards), I have practiced philosophy as an "embedded" philosopher, holding a philosophy chair at a Faculty of Science, teaching philosophy to science students and collaborating with scientists in research projects devoted to genomics, synthetic biology and neuro-science. These experiences shaped my outlook no doubt. Should we become guardians of the philosophical past or critics of the Anthropocenic, technoscientific present? Already as a philosophy student I encountered these two positions, like signposts pointing in opposite directions (either towards author studies or towards more applied forms of philosophical analysis). But it is a false dichotomy, I will argue, because a philosophical assessment of contemporary technoscience is only possible against the backdrop of an extended temporal horizon ${ }^{2}$ and requires a solid embedding in the history of philosophical thinking. At the same time, our vocation is to revivify and rethink this tradition, by exposing it to contemporary developments in global technoscience and their impact on the planet.

Furthermore, I will argue that the development of a philosophical assessment of contemporary technoscience requires both proximity and distance. Philosophy should be practiced as philosophy in science. Philosophers should be there, should be in research, should familiarise themselves with emerging contexts of global technoscientific discovery. At the same time, these contexts of discovery are not to be assessed from an "empirical" (e.g. sociological or ethnographical) perspective, but from a philosophical angle, from an "oblique" perspective, based on critical dialogue and self-reflection (Zwart 2017a). In other words, when it comes to rethinking the relationship between philosophy and technoscience, we should recognise that the (seemingly innocent) word "and" suggests a deceptive dichotomy. There is more philosophy at work in contemporary technoscience than scientists (and philosophers, for that matter) tend to be aware of, and our vocation is to bring

\footnotetext{
${ }^{1}$ Contrary to how Evans (2008) somehow reads it, Kant's Conflict of the Faculties does not at all contain a plea for philosophers as marginal "lone scholars" (p. 490), but rather as engaged scholars, critically involved in research conducted at other faculties, entering into deliberations about research with animals for instance with colleagues at the medical faculty, or about rationality and revelation with colleagues at the theological faculty.

2 The challenge of contemporary philosophy is to broaden the temporal horizon of the debate (Zwart 2009). The point of commencement (the global awakening) should not be the Achsenzeit, i.e. the birth of contemplation (twenty-five centuries ago, at various places on earth, more or less simultaneously, but independently from one another), but rather the birth of human transformative praxis, notably the Neolithic revolution (ten millennia ago, at various places on earth, but again more or less independently from one another).
} 
this inherent philosophy (these latent philosophemes) to the fore, so as to become conscious of them and question them, from a position of close proximity, in dialogue with the practicing scientists involved. For as Hegel already convincingly argued, if we fail to master them (through conscious conceptual analysis), these implicit convictions will unconsciously master us (1812/1986a, p. 25). Scientists and philosophers will both benefit from this mutual exposure, this dialectical interpenetration of praxis and reflection.

There is a third misguiding dichotomy, moreover, again suggested by the word "and", but this time in the phrase "science and society". Here again, we are actually facing mutual interpenetration (Levins and Lewontin 1985, p. 5). Science and society mutually pervade one another. In contemporary social environments, technoscience is omnipresent and pervasive, while socio-economic and socio-cultural realities are emphatically present in technoscience as well. The Anthropocene concept refers precisely to this: the mutual interpenetration of contemporary technoscience and the global lifeworld (Lemmens and Hui 2017).

\section{The Oblique Perspective: Towards a Philosophical Dialectics of Technoscience}

How to practice philosophy in technoscience? As Serres (1972) already argued, in the present era of disruptive change, exemplified by the emergence of large-scale, high-tech, trans-disciplinary research fields such as molecular biology, philosophy runs the risk of losing track, of becoming outdated and irrelevant. Philosophers may still play a vital role, Serres argues, provided they acquaint themselves with these newly emerging "oceans" of knowledge opened up by technoscience, from a position of close proximity, entering the tissues and capillaries of emerging research arenas as embedded scholars, addressing philosophical issues raised by these developments in close interaction with the scientists involved. Philosophy then becomes "conceptual epidemiology": analysing and assessing how techniques, vocabularies, concepts, metaphors and research practices spread through research fields worldwide, infecting and inflaming the global societal life-world as well.

Whereas for many centuries, philosophy and natural science ("physics") remained identical endeavours more or less, the process of differentiation and alienation depicted by Serres began during the modern era but continued up to this day, giving rise to scientific forms of research that consider themselves independent of and indifferent to, or even antithetical to, philosophical reflection. From a dialectical perspective, such antagonisms or polarisations represent a "negative unity" (Hegel 1812/1986b) in the sense that, unwittingly perhaps, both genres of discourse still depend on one another and are even drawn towards one another. Subliminally, particular philosophical convictions ("philosophemes") are still at work in science, but in an unconscious manner as it were. ${ }^{3}$ For philosophy this means: bringing these tacit philosophical convictions to the fore by addressing questions that are usually not raised by practicing scientists themselves, such as: What is nature? What is life? What is science? It means using our philosophical hammers and stethoscopes

\footnotetext{
${ }^{3}$ Even if philosophy and science operate as antagonistic poles, they are still drawn to one another. Whereas philosophy holds on to contemplation (resisting the modern scientific drift towards experimentation and quantification), there is nonetheless an urge to develop rigid methodologies (e.g. propositional logic, linguistic analysis, phenomenology, etc.) and whereas science replaces contemplation by technoscientific experimentation, there is still an awareness that the conceptions produced by laboratory work require systematic philosophical processing.
} 
to develop a diagnostic of the technoscientific present, reading technoscientific papers with a philosophical eye and listening to technoscientific deliberations with a philosophical ear. Rather than in viruses, microbes, Higgs bosons or black holes, philosophers will be interested in the ways these entities are envisioned and addressed. We focus our intentionality neither exclusively on the object pole (as scientists tend to do) nor exclusively on the subject pole (as sociologists and ethnographers of science tend to do), but rather on the interaction between subject and object, on the mutual interpenetration of both poles, exploring how scientific technicity allows nature to appear and on the inherent ontological convictions that materialise in specific research objects. In other words: the axis of attention is tilted, urging us to take a quarter turn, following technoscientific debates with evenly-posed attention ('gleichschwebende Aufmerksamkeit'), as Freud famously phrased it, to discern the unconscious philosophemes at work in technoscientific practice. At a certain point in this stream of technoscientific discourse, something questionable may suddenly emerge which triggers our attention and entices us to take a more critical and active stance.

The oblique perspective is not at all a new idea. Aquinas ${ }^{4}$ (1922) already stated that, whereas human understanding is initially directed towards external reality (the "object"), critical reflection on human understanding (philosophy) requires a change of perspective, an intentio obliqua. Along these lines, a diagnostic of contemporary technoscience should be developed today: a critical assessment of the way in which technoscience (as a particular instantiation of logos and as a particular way of being-in-the-world) allows reality to emerge.

This idea (philosophy as an oblique perspective) was fleshed out by Hegel (1807/1973), notably in the Introduction (Einführung) to the Phenomenology of the Spirit (Phänomenologie des Geistes). While science is about understanding (knowing) the object, philosophy aims to understand this knowing: how are scientific objects known by science? Philosophy is a critical assessment of the ways in which science allows reality to appear. It is an exposition of scientific research practices as they appear on the scene: the path or journey of scientific consciousness towards optimised knowledge: passing through a series of configurations or stations of knowledge towards more comprehensive forms of understanding. In short, philosophers aspire to develop knowledge about knowing. For philosophers, science itself is a phenomenon, and philosophy is a dialectical "phenomenology" of scientific experience, discerning the basic logic that guides the development of scientific consciousness. As Engels (1878/1962, 1886/1962, 1925/1962) already argued, however, what should be added to Hegelian dialectics is that, to fathom knowing (i.e. science), we should pay due attention to the technicity of science, to its technological base: the technoscientific means of knowledge production, guided by the realisation that science is a very active ("tätig"), performative and transformative style of thinking, technology-driven: technoscience.

If we look at science (technoscience) from an oblique perspective, Hegel argues, what inevitably strikes us is the resolve of science not to rely on the authority of others (1807/1973, p. 73): the desire to produce knowledge yourself and to accept only your own products as valid and convincing, even if this initially entails a dramatic loss of knowledge

\footnotetext{
${ }^{4}$ Besides Aristotle and Hegel, Aquinas (1922) should be listed as a prototypical dialectician. See for instance the systematic triadic manner in which he structured his questions: Videtur (it seems to be the case that, the first moment, presenting allegedly self-evident conviction in a general sense); Sed contra est (presenting particular conflicting arguments, challenging the initial position); Conclusio (stating a more comprehensive view on a higher level of comprehension, but building on the experiences gained during the triadic process).
} 
(sacrificing and negating inherited worldviews). Science is the zealous resolve to follow this process to completion, moreover, notwithstanding multiple experiences of doubt and despair. Science, Hegel argues, is an unhalting process which finds no satisfaction in intermediary stations of knowledge (p. 74) and we should acknowledge this unrest of science which unceasingly disturbs and spoils its own satisfaction: the relentless drive to take the knowledge process further. This is what invokes both fascination and uneasiness (Besorgnis, Misstrauen, p. 69): the negativity, the Faustian, disruptive dynamics of scientific practice which often eliminates more than it creates.

My question, during the past two decades, has been: how to be a Hegelian philosopher in technoscience today: how to extrapolate and enact a dialectical approach during the Anthropocenic present $?^{5}$ In this paper, I will use my own philosophical experiences as source material, analysing some of the technoscientific projects I was actively involved in as concrete dialectical "case studies". I will begin at the beginning, in the literal (biographical) sense, for as it happened, I received my formal letter of appointment as an inhouse philosopher at a Faculty of Science on June 26, 2000. Exactly on that same day, an important technoscientific event was staged across the Atlantic, at the White House in Washington D.C.

\section{June 26, 2000}

The year 2000, also referred to as MM or Y2K, was a remarkable year for various reasons. First of all because (in terms of the Anno Domini calendar) it constituted the turning point between the second and third millennium. MM was also a remarkable year for technoscience, however. Let me just mention a few events. On January 6, 2000, the last individual belonging to the species Pyrenean ibex (a famous mountain goat of the Pyrenees) was found dead, apparently killed by a falling tree. Subsequently, the birth of five cloned piglets was announced on March 5, 2000, at PPL Therapeutics in Edinburgh, named Milly, Christa, Alexis, Carol and Dotcom. Two months later, on May 5, 2000, the computer virus ILOVEYOU began to infect millions of Windows personal computers around the globe, spreading quickly through global electronic networks (causing far more damage than the anxiously anticipated, but eventually harmless Millennium bug). And finally, on June 26, during a carefully orchestrated Press Conference, the draft version of the human genome sequence was proudly presented to a live audience (congregated at the White House), but also to a global audience (Urbi et Orbi as it were) by President Bill Clinton and two prominent scientists, Francis Collins and Craig Venter.

To assess the significance of these events, we have to zoom out as it were, taking a step backwards in time, although this should be complemented by a subsequent step forward (exploring the emerging future) later on. This stepping backwards and forwards, to position

\footnotetext{
5 This paper may be regarded as an affirmative response to a question raised by Žižek (among others): "Is it still possible to be a Hegelian today?" (Žižek 2012/2013, p. 193). "Is there a place for modern science in Hegel? Is not the explosive growth of the natural sciences from the eighteenth century onwards simply beyond the scope of Hegel's thought?" (Ibid., p. 458). My aim is to demonstrate that a Hegelian approach to technoscience is not only possible, but more urgent and relevant than ever: a position which aims to overcome the currently more dominant view, articulated by Žižek (and others): "What even the most fanatical partisan of Hegel cannot deny is that something changed after Hegel... There is a clear break between before and after and one cannot really be a Hegelian after this break. To act like a full Hegelian today is equivalent to writing tonal music after the Schoenbergian revolution” (Žižek 2012/2013, p. 237).
} 
the present within the broader landscape, is an essential methodological component of the oblique (dialectical) perspective.

The step backward takes us to the year 1900, likewise a remarkable date (an annus mirabilis) for technoscience, when the work of Gregor Mendel was suddenly rediscovered and Max Planck introduced the quantum concept (Zwart 2013). In the same year, Sigmund Freud officially published The Interpretation of Dreams (although the actual publication date was 1899) and Edmund Husserl inaugurated the birth of phenomenology by publishing his philosophy classic Philosophical Investigations (Philosophische Untersuchungen). In many ways, the year 1900 can be regarded as a new beginning-the Anfang-of a process that would be brought to completion around the year 2000. The rediscovery of Mendel for instance set the scene for the rise of genetics and, in combination with quantum physics, spectrophotometric analysis and molecular biology (during the second half of the twentieth century), culminated in the sequencing of the human genome, a project that was launched in 1989, the year of the collapse of the Berlin Wall. Meanwhile, the quantum concept paved the way for elementary particle physics, culminating in the hunt for the inexorable Higgsboson in the Large Hadron Collider (LHC) at CERN. As Erwin Schrödinger convincingly argued, however, genetics and quantum physics are interpenetrating endeavours. They not only mirror one another, but also combined forces to tackle the ultimate technoscientific question: What is Life (Schrödinger 1944/1967).

Against this backdrop, we can begin to make sense of the events briefly listed above. The Pyrenean ibex quickly became the target of a technoscientific endeavour to resurrect this extinct species on the basis of its genome. On October 8, 2000, a biotech company began to use nuclear transfer technology to clone the Pyrenean ibex back into existence, a process currently known as de-extinction: the negation of the negation, dialectically speaking. On July 30, 2003, a clone was born alive, but died several minutes later due to lung defects. Although technically speaking the project failed (its negative result), it did reveal that, in the era of genomics and biotechnology, extinction is bound to become a relative concept, a technoscientific variable (its positive result). Somewhere in the near future it may work. Via genomics and other transdisciplinary research areas, the sway of technoscience over living nature increases dramatically, although at the same time the astounding complexity of living systems continues to represent a challenge for the technoscientific will to power.

A similar message is conveyed by the second example, the five cloned piglets. Technoscience instrumentalises living nature, making it increasingly modifiable and anthropocompatible. The idea is that in the nearby future, cloned animals (notably piglets) will become available as resources for procuring organs (xenotransplantation) to enable human life-extension. The names of these piglets were symptomatic as well, for while Alexis and Carrell referred to a once-famous organ transplantation pioneer (Zwart 2001), Dotcom evidently hinted at Internet and the WWW or, more generally, at the decisive role of computers and computer networks in cutting-edge technoscience. Although organisms and computers initially seem completely different things (organisms versus artefacts), they are becoming increasingly interconnected, as genomes are basically regarded as programs or codes, comparable to computer code and usable for data storage. Dialectically speaking, this intimate connectivity of the natural and the artificial represents the interpenetration of opposites.

This interpenetration is likewise exemplified by the symptomatic phenomenon of the computer virus, of which the ILOVEYOU virus (the third event) was a telling instantiation. Both organisms and computers can be infected by viruses (entities which are basically nothing but packaged pieces of potentially detrimental and quickly replicating code). 
Moreover, the computer virus also exemplifies the trans-continental interconnectedness of everything in our global world.

During the June 2000 press conference, the Human Genome Project (HGP) was presented as a kind of closure or completion: a point of convergence, not only for genomics as such, but for a whole century of research, starting with the rediscovery of Mendel's work in 1900. In the aftermath of the event, however, the initial enthusiasm quickly became eclipsed by a sense of disappointment and failure. The project had started from the claim that we basically are our genome and that, by sequencing this genome, we will be finally able to know ourselves. But the result of the project was that there is nothing special about our genome, no defining factor $\mathrm{X}$ setting us apart from other species, so that the sense of triumph was reverted into a defeat and the project's basic philosopheme (i.e. genetic determinism) was actually negated (Zwart 2007). Dialectically speaking, this was a crucial experience. While there is nothing special about our genome (which can be seen as the universally human, techno-scientifically speaking), our uniqueness resides in the fact that humans are the only species able to sequence their genome (and be disappointed by the results), using technoscience to reflect on our own identity and evolution. ${ }^{6}$ Dialectically speaking, the starting point, the basic concept, the first moment, ("We are our genome", i.e. genetic determinism: $\mathrm{M}_{1}$ ) proved questionable and was inevitably negated by the very project designed to confirm its validity: the second moment $\left(\mathbf{M}_{2}\right)$. Life in general and human existence in particular is far more complex than Francis Collins et all initially expected (Collins 2011; cf. Zwart 2011). The HGP undermined (negated) rather than confirmed a genetic reductionist understanding of the genome as our "blueprint": our "concept" (Begriff), embodied in our organism (Hegel 1830/1970a, § 216, p. 373). ${ }^{7}$ Refutation does not imply, however, that the opposite is true and that we are not our genome. The initial conviction remains partially valid, but is now "lifted up" (sublated) and incorporated into a more comprehensive view which sees organisms as resulting from complex interactions between heredity and the environment. Contrary to the high expectations evoked at the start of the project, moreover, there were hardly any biomedical applications or innovative therapies to report, nothing of the kind. This was the negative result: the gap between the outcomes of a project (which apparently built on a one-sided, deficient concept), and life as a fully realised idea. Yet, as a positive result, a whole new series of research initiatives were developed in response to this disappointing outcome, this experience of defeat, in order to negate and overcome the ensuing negativity, the deadlock. In other words, by negating the negation (by incorporating and working-through the apparently negative result), post-genomic research can now advance towards a higher plane of comprehension and sophistication.

These initiatives meant to address and compensate the one-sidedness of the initial idea by developing a more comprehensive view on life: the third moment $\left(\mathrm{M}_{3}\right)$. In "personalised genomics", for instance, the focus shifted from the universal genome (Das Allgemeine, as Hegel phrases it: A) to the complex interactions (e.g. between genetic and environmental factors) on the concrete level of individual functioning (the level of Einzelheit, as Hegel

\footnotetext{
6 "Dadurch, dass der Mensch weiß, was er ist und was er tut, unterscheidet er sich vom Tier" (Hegel 1830/1970a, § 19 Zusatz, p. 70).

7 "Der Kampf der Vernunft besteht darin, dasjenige, was der Verstand fixiert hat, zu überwinden" (Hegel 1830/1970a, § 32 Zusatz, p. 99). In this case: the fixation on genetic determinism (on the conviction "we are our genome' as the initial abstract philosopheme of genomics) was overcome by the dialectics at work in the actual research process.
} 
phrases it: E). Thus, rather than a moment of synthesis and conclusion, the HGP came to represent a transitory stage, a turning point, a moment of transition. While genomics can be seen as the final, most radical or extreme step in the effort to reduce the phenomena of life to elementary bio-particles (e.g. nucleotides, amino acids and the like), the next inevitable step now was to move from sequencing ("reading") genomes to rewriting them, which is where CRISPR-cas9 technologies come in (Zwart 2012). This entails a shift from analysis to re-synthesis: the technoscientific reproduction of life in vitro, putting the pieces together again to see whether and to what extent life has now indeed been brought under technoscientific sway.

This "holistic" turn is exemplified, I will argue, by the endeavour to create a synthetic cell. How to assess this project from a dialectical perspective? How to practice philosophy (dialectics) in confrontation with this exemplification of contemporary technoscience?

\section{Creating a Synthetic Cell In Vitro}

In 2017, the BaSyC project ("Building a Synthetic Cell") ${ }^{8}$ was launched, funded by Netherlands Organisation for Scientific Research (NWO). The project's objective is to build a synthetic cell "bottom-up", starting from basic components and resulting in an entity which convincingly mimics the functioning of living cells, from metabolism up to self-replication. As a philosopher in science, I am a principal investigator in this project. During the past twelve decades, from 1900 onwards, living cells have been effectively dissolved into their basic molecular and informational components, and now time has come to venture a holistic turn, putting all these components together again, in order to address the question: do we really understand life, or have we missed something (Zwart 2019a, b)? BaSyC conveys an engineering view of life. It starts from the (philosophical) conviction that we can only genuinely understand life insofar as we are able to technologically reproduce it. ${ }^{9}$

Techno-scientifically speaking, the only way to ascertain whether our concept of life is adequate is to actively realise and materialise this concept in the form of a synthetic cell. Indeed, to effectively demonstrate that the noumenal essence of life has been grasped, we should be able to produce something in vitro which not only maintains its internal self-sustaining metabolism but can actually reproduce itself. At the same time, the very concept of a synthetic cell seems self-contradictory, as a conjunction of the artificial and the natural. Dialectically speaking it is to be expected that the synthetic cell, as a concrete instantiation (E) of the technoscientific idea of life currently in sway, will lack something, revealing a deficiency compared to life as we conceive it in general conceptual terms (A). But this then may put us on the track of new pathways of research. As indicated, my intention is not only to show how dialectics allows us to come to terms with the synthetic cell. The latter also allows us to demonstrate the remarkable significance of Hegelian dialectics when it comes to assessing contemporary life sciences research. ${ }^{10}$

\footnotetext{
8 http://www.basyc.nl.

9 This conviction (this philosopheme) is explicitly addressed by Daphne Broeks in her research: https:// www.ru.nl/english/people/broeks-d/.

10 I consider Hösle's statement, made more than three decades ago, even more valid now than it was then: "Auf Basis der modernen Molekularbiologie lässt sich eine erstaunliche Aktualität der Hegelschen Ausführungen nachweisen" (1987, p. 314).
} 
To assess the project in dialectical terms, my starting point is Hegel's contention (already referred to above) that there is more philosophy at work in contemporary technoscience than scientists are aware of or willing to acknowledge (Hegel 1830/1970a, § 38, p. $109 ; 1830 / 1970$ b, p. 11). Research practices are guided by philosophical convictions (philosophemes) concerning life, nature, science and knowledge. The claim, for instance, that we only genuinely understand life if we can technologically reproduce it under laboratory conditions, is an example of a guiding philosopheme. Insofar as this project will contribute to our understanding of living nature, however, it will strengthen a decidedly technoscientific view of life and nature, urging us to see life and nature from a laboratory angle, so that nature as such emerges as an immense laboratory where myriads of experiments are continuously being conducted. This raises the question whether the technoscientific approach to nature really allows us to fathom 'natural nature' as such (whether the laboratory view of nature concurs with the idea of life as it realises itself in real, genuine nature). The synthetic cell project may seem to present a final answer to the question "What is life?", but nature may reveal itself in completely different and unanticipated ways. In other words, from a philosophical perspective, the BaSyC project exemplifies the gigantomachia currently raging concerning questions such as: What is being?, What is nature?, What is technology?, What is life?

The synthetic cell project represents the inevitable transition, already envisioned by Hegel, from chemistry (unsustainable processes) to biology (self-sustainable processes). Hegel envisions this transition in his dialectical analysis of the chemical process (Hegel 1830/1970b, § 326 Zusatz p. 292; § 335 Zusatz p. 333) where he argues that the chemical process is an analogue of life, in the sense that, if the chemical process would continue itself spontaneously, it would be life. ${ }^{11}$ There is a glimpse of vitality in the chemical process (Hegel 1830/1970b, § 335 Zusatz; Ferrini 2011, p. 208). Contrary to the chemical process, which does not renew or reproduce itself on its own accord, life is a self-renewing chemical process made perennial. Dialectically speaking, creating a synthetic cell means creating a technoscientific constellation where the metabolism of chemistry becomes selfrenewing and where entropy (the natural tendency towards disruption) becomes negated and sublated, thus giving rise to "negative entropy", as Schrödinger (a quantum physicist, but also a gifted dialectician) phrased it (Schrödinger 1944/1967). ${ }^{12}$ The transition of the chemical process towards biotic metabolism entails that entropy gives rise to negative entropy (negentropy) as a signature feature of living beings (Levins and Lewontin 1985, p. 17). Negentropy is the "negation of the negation", dialectically speaking, so that complex chemical processes (disruptive or finite metabolism) become self-sustained. In everyday language this is known as creating life in a test-tube.

\footnotetext{
11 "Der chemische Prozess ist so ein Analogon des Lebens. Könnte er sich durch sich selbst fortsetzen, so wäre er das Leben; daher liegt es nahe, des Leben chemisch zu fassen" (Hegel 1830/1970b, § 326 Zusatz, p. 292); "Wenn die Produkte des chemischen Prozesses selbst wieder die Tätigkeit anfingen, so wären sie das Leben. Das Leben ist insofern ein perennierend gemachter chemischer Prozess" ( $\$ 335$, p. 333).

12 "Probably, it is not too much to say that scientists working in biology have successfully accomplished, with brilliant results, realizing the ideas described in the first chapters of [Schrödinger's] book" (Saks et al. 2009, p. 1168).
} 


\section{The Inherent Negativity of Technoscience}

What is a test-tube? At first glance, a test-tube may seem a trivial, quasi-self-evident laboratory item, producible on a massive scale, but on closer inspection (from an oblique perspective), it is actually a rather remarkable thing. It is something completely transparent and empty, a thing which comes close to (which verges on) nothingness: an artificial void, an object without properties, a minimal object, a pure container. All properties have been obliterated and stripped, until all that remains is a translucent glass membrane. This empty test-tube is waiting for something, standing in waiting, standing out towards something, it is designed to become the recipient of an enigmatic and highly valuable "something" which is not yet there and whose ontological status seems highly uncertain: on the boundary between living and non-living, between natural and artificial. The thing which finally comes to fill the tube is likely to be something contentious, a thing which calls for a "Thing", in the original sense of the term, as Heidegger (1951/1954) argued: a gathering, a deliberation, a dispute, a critical assessment, a review. Will this thing, this something (this novelty) pass the test? The empty tube inevitably refers to something which one day may come to occupy (and thereby negate) its emptiness, as the enigmatic object of technoscientific desire: the negation of the negation. In short, the test-tube embodies the three stages of the dialectical unfolding. In order to understand the natural object as it presents itself to us (the first moment: $\mathrm{M}_{1}$ ), technoscience creates a clearing, an empty space, where (almost) everything is negated and eliminated $\left(\mathrm{M}_{2}\right)$ : a very particular ambiance consisting of virtually nothing, but therefore (almost) completely under our control. An object without properties is bereft of its potential for recalcitrance. All opaqueness is cleared, all resistance eliminated. And it is precisely here that something will occur or will emerge. If it comes about, the synthetic cell will be the concrete culmination and convergence of countless partial insights, acquired during decades of test-tube research, but now reassembled in a concrete singular entity, containable in a tube $\left(\mathrm{M}_{3}\right)$.

The test-tube (as a materialisation of nothingness) exemplifies the dynamics of technoscience as such, which always commences with the creation of a void, a clearing. Take Newton's optical experiments, conducted in the wonder year (annus mirabilis) 1666. In order to study light, Newton paradoxically created darkness: a dark room, a camera obscura, a darkened barn. Here, he made a little hole in the wall, an artificial orifice, a pupil so to speak, to allow a minimum of light (a small beam of sunlight) to enter the darkness, small enough to be easily manageable and modifiable with the help of a prism. ${ }^{13}$ He thus created an artificial eye, with a pupil (the hole), a lens (the prism) and a retina (for the prism forced the beam to diffract into a spectrum, projected against a screen). You cannot see, let alone manipulate light unless you create darkness first. Optics begins with the negation of light, which may seem paradoxical but is quite inevitable from a dialectical perspective, because in order to analyse something, it should be allowed to stand out against a backdrop which represents the opposite extreme.

The same applies to studying life. To study it, life first of all has to be negated. Technoscientists create an abiotic, gnotobiotic ("clean") environment where life has been obliterated: the laboratory, the sterilised test-tube, where real (natural) life is kept at bay. Here, isolated instances of life are deliberately introduced, partial biotic objects, single cell

\footnotetext{
${ }^{13}$ Cf. the question raised by the nuns' choir in The Sound of Music: "How do you hold a moonbeam in your hand?" Techno-scientifically speaking, Newton had already solved the challenge.
} 
organisms or bacteriophages, for instance. ${ }^{14}$ They become fully modifiable in an Umwelt which actually is the negation of any natural Umwelt, so that the object (the entity under study) cannot be contaminated by real life. Here, the trapped entity becomes life in general (das Allgemeine), life as such (an sich). A laboratory is a particular kind of clearing where life can be optimally controlled, against an abiotic backdrop of negativity. Where the natural is eliminated, neo-life can emerge.

This negativity is an inherent feature of science, albeit pushed to its extreme by contemporary technoscience. It may seem paradoxical, but it is actually quite inevitable. Suppose technoscience aims to understand the functioning of a tree. During the first moment $\left(\mathrm{M}_{1}\right)$ we discern the tree as it presents itself to us, as a natural phenomenon: a Gestalt in a natural Umwelt, clad in natural daylight. Once this tree is taken into a laboratory setting, however, negativity sets in. In order to understand a living being, it has to be taken apart, eliminated. Technoscience will never be satisfied until this process is pushed to its extreme. During this process we discover that the tree as such (an sich) basically consists of cellulose, a compound whose chemical composition can be revealed $\left(\mathrm{C}_{6} \mathrm{H}_{10} \mathrm{O}_{5}\right)$. The living tree is obliterated, replaced by chemical symbols $\left(\mathrm{M}_{2}\right) .{ }^{15}$ Technoscience cannot be satisfied until the tree as it initially appears to us (the living phenomenon) is reduced to its basic noumenal ${ }^{16}$ components, so that we may reach the conclusion that the tree $=\mathrm{C}_{6} \mathrm{H}_{10} \mathrm{O}_{5}$. The more technoscience is in control (predominates), the more the naturalness and immediacy of living beings will vanish away, so that their richness becomes impoverished (Posch 2011, p. 189). Dialectically speaking, this is both inevitable and rational, but it is also a disquieting experience, because we have evidently lost something underway: the living organism as a whole. How to retrieve this original, organic, organismal whole?

This is where the third moment $\left(\mathrm{M}_{3}\right)$ sets in: somehow the negativity of technoscience itself has to be negated (the negation of the negation) via a concrete countervailing intervention. This return (Zurückführung) from splitting (Entzweiung) to wholeness (Einigkeit) is not a return to the original, purely natural situation of course, but brought about by a conscious, technoscientific intervention (Hegel 1830/1970a, § 24 Zusatz3, pp. 88-89). The splitting (Entzweiung, Zerlegung) of natural entities is not only a result of human labour but is also overcome (sublated, counteracted) by human labour (p. 89).

In the next section, this will be unravelled in more detail, but before doing so I once again would like to emphasise that, whereas technoscientific research fields such as biology

\footnotetext{
14 "[Der Mensch] fixiert Einzelnes, hebt es heraus, nimmt es als ein ... Abstraktes und Allgemeines" (Hegel 1830/1970a, § 24, Zusatz, p. 83).

15 "Die empirische Welt denken heißt, ihre empirische Form umändern und sie in ein Allgemeines verwandeln; das Denken übt eine negative Tätigkeit aus; der wahrgenommene Stoff ... bleibt nicht in seiner ersten empirischen Gestalt. Es wird der innere Gehalt des Wahrgenommenen mit Entfernung und Negation der Schale herausgehoben" (1830/1970a, § 50, p. 132).

${ }^{16}$ Whereas pre-modern philosophy believed in the correspondence between thinking and being ("Die Übereinstimmung des Gedankens mit der Sache", Hegel 1830/1970a, p. 79: $\mathbf{M}_{1}$ ), modern thinking (notably critical philosophy) negated this initial position by emphasizing the gap (Gegensatz, das Getrenntsein) between human cognition and the things in themselves $\left(\mathrm{M}_{2}\right)$, in view of the finitude of human thinking and the constraints of human perception. Contemporary technoscience, however, has dramatically expanded not only our range of perception (via precision instruments for measurement and data collection) but also our thinking capacity (via artificial intelligence, in combination with the distributed intelligence of global research networks). This gave rise to a series of qualitative leaps in human research power, which was outsourced to machines and became increasingly independent of the limitations of human cognition and sensitivity, so that new research fields (e.g. quantum physics, molecular life sciences, etc.) are now able to bridge the gap, disclosing the noumenal dimensions of natural objects, processes and entities $\left(\mathrm{M}_{3}\right)$.
} 
or biochemistry are about knowing the chemical composition of an organism, dialectics aims to understand what is gained and lost during this process of knowing, for dialectics (as we have seen) is knowing about knowing. This not only allows us to clarify the relationship between philosophy and technoscience, it also helps us to elucidate the difference between dialectics (philosophy in technoscience) on the one hand and social science and empirical research (e.g. sociology or ethnography) on the other. Yes, the oblique perspective of dialectics entails an empirical moment in the sense that its intentionality is focussed on research as a praxis, on the ways in which biochemistry or synthetic biology are actually practiced, and this may include a phenomenological assessment of the test-tube as a particular intriguing something (as we have seen). But the key objective is to fathom technoscience as a particular way of being-in-the-world, giving rise to particular experiences, and the laboratory (or even the test-tube) as a particular kind of clearing, allowing life or nature to emerge in a certain manner. The laboratory is a particular ambiance where a particular praxis unfolds and dialectics allows us to discern the basic experiences of loss and progress (in the dialectical-phenomenological sense of the term) entailed in biochemistry or molecular biology, as stations on the pathway towards comprehensive knowledge.

\section{The Synthetic Cell Project: Three Moments}

Let this suffice as a first exploration and let us now flesh out the oblique dialectical assessment of the synthetic cell project in more detail. Three moments can be discerned in this unfolding as we have seen. The first moment $\left(\mathbf{M}_{1}\right)$ involves natural entities as they present themselves to us, as natural phenomena observed by us, whose integrity is respected by us (the Latin verb observare means to observe, but also to respect).

During the second moment $\left(\mathrm{M}_{2}\right)$ negativity sets in. Here, we are confronted with the paradoxical conviction (inevitable but disruptive) that, in order to understand something, this entity must be dissected and taken apart. Pushed to its extreme, this means completely destroying it. Analysis (Zerlegung in German) is a negative and inherently violent endeavour. Instead of letting things be, we not only separate them from their natural habitat, but also dissect them. ${ }^{17}$ Molecular biology and genomics represent the most radical instantiations of this negativity, this negation of living beings, for they aim to reduce living nature to its most basic noumenal components, so that the original living thing becomes literally obliterated (i.e. replaced by letters, e.g. the four letters of the nucleic alphabet, A, C, G and T). ${ }^{18}$

\footnotetext{
17 "Um Erfahrungen zu machen, bedient sich der Empirismus [empirical science] vornehmlich der Form der Analyse: die Tätigkeit des Zerlegens. Die Analyse ist der Fortgang von der Unmittelbarkeit der Wahrnehmung zum Gedanken... Der Empirismus, indem er die Gegenstände analysiert, befindet sich in Irrtum, wenn er meint, er lasse dieselben, wie sie sind, da er doch in der Tat das Konkrete in ein Abstraktes verwandelt. Hierdurch geschieht es zugleich, dass das Lebendige getötet wird... Gleichwohl muss jene Scheidung geschehen, um zu begreifen... Dies ist jedoch nur die eine Seite, und die Hauptsache besteht in der Vereinigung des Geschiedenen" (Hegel 1830/1970a, § 38 Zusatz, pp. 109-110).

18 "Die Tätigkeit des Erkennens] besteht darin, das gegebene Konkrete aufzulösen: die analytische Methode... Das Erkennen ist zunächst analytisch ... und die Tätigkeit des analytischen Erkennens ist darauf gerichtet, das demselben vorliegende Einzelne auf ein Allgemeines [Stickstoff, Kohlenstoff, Wasserstoff, usw.] zurückzuführen ... die gegebenen konkreten Gegenstände in ihre abstrakte Elemente zu zerlegen und diese dann in ihre Isolierung zu betrachten. Es erhellt indes zugleich, dass das Erkennen, welches die Dinge nehmen will wie sie sind, hierbei mit sich selbst in Widerspruch gerät" (Hegel 1830/1970a, § 227, p. 380).
} 
The synthetic cell project, however, represents a third moment $\left(\mathrm{M}_{3}\right)$ : the holistic turn, which inevitably announces itself as soon as the process of analysis is being brought to its most radical completion (when living beings are effectively reduced to their most elementary molecular and informational components). In other words, the synthetic cell project represents the negation of the negation, the return of the whole, but now on a higher plane of comprehension and technoscientific sophistication. ${ }^{19}$ Similar to how a living organism summarises everything that precedes it (matter, electricity, chemical processes, etc.: Malabou 1996/2005, p. 59), a synthetic cell summarises (becomes a comprehensive technoscientific Summa of) all partial scientific experiences since the onset of contemporary life sciences research around the year 1900.

Building on Hegel's dialectical logic (Hegel 1812/1986a, 1812/1986b), we can also capture this dynamic in somewhat different terms. Initially, during the first moment $\left(\mathrm{M}_{1}\right)$, life is understood and described on a general level. Life is here understood in universal terms, for instance by defining the concept of life as such (das Allgemeine [the universal], A). Life here is disclosed as an abstract, universal principle and living beings are regarded in abstract terms, as living universalities as it were (as "model organisms", as technoscience phrases it). Subsequently, however, during the second moment $\left(\mathrm{M}_{2}\right)$, the intentionality of technoscience focusses on particular components (das Besondere [the particular], B). To enable this, living entities must be broken down or even destroyed, as we have seen. At this stage, life emerges as composed of particular dimensions which present themselves as opposites: as programs (DNA) versus processes (metabolism), heredity versus environment, nature versus nurture, etc. In laboratory settings, these particular dimensions are considered in isolation from one another (this is what is meant by "pure" science). The focus is on a specific aspect of life, a partial object, isolated from natural life (from living nature) as such.

Finally, however, this focus on particular and juxtaposed dimensions inevitably gives way to the awareness that, on the level of concrete living beings, life actually emerges as the mutual interpenetration of such opposites, but now reintegrated into a concrete living entity, an organism. Here, a biological entity emerges as the instantiation of the universal concept of life: as the singular (das Einzelne [the singular], E). Fully developed and individuated, it becomes the concrete universal (Hegel 1812/1986b, p. 298). On the level of the concrete organism, we realise that there is no process without a program (and vice versa), no heredity without an environment (and vice versa), no nature without nurture (and vice versa), no continuity (survival) without adaptation, and so on. All such oppositions become sublated as aspects of a concrete living entity. Both in nature and in science (both at the object and at the subject pole) we discern this dialectical drive to reintegrate these partial products and separated components into a concrete, convincing whole (Hegel 1830/1970a, $\S 200$ Zusatz, p. 357; § 214, p. 371).

In our case study, the concrete synthetic cell represents precisely this third moment, referred to by Hegel as Einzelheit (E). It is a concrete thing (konkrete Einzelheit): the concrete realisation of the inevitable turn towards holism, i.e. the strive towards reconstruction and re-convergence. And insofar as this goal is reached (and a functioning,

\footnotetext{
19 Saks et al. (2009) discern a similar pattern. Whereas reductionism has been the philosophical basis of biochemistry and molecular biology for the last six decades, this is now being displaced by systems biology, which favours the study of integrated systems: the higher-level analysis of complex biological systems. These developments, they argue, "follow very precisely the dialectical principles of development" discovered by Hegel (p. 1161).
} 
self-replicating entity is indeed created), the synthetic cell materialises the concrete universal (the concrete instantiation of our universal understanding of life, the concrete realisation of our idea of life). These three moments $(\mathrm{A}>\mathrm{B}>\mathrm{E})$ represent the dialectical unfolding, starting from life as something universal, integral and whole (A), via the focus on particular processes and components (B), until individuation is regained on a higher level of comprehension, but now in the form of something very concrete: a metabolic and self-replicating synthetic cell in a test-tube (E). Dialectically speaking, this is how technoscience evolves as a praxis, involving a series of elucidating experiences: from respectful observation via disruptive analysis up to technoscientific individuation.

The suggestion that the synthetic cell represents what in Hegelian dialectics is known as the "concrete universal" not only allows us to elucidate the dialectical profile of this questionable entity (whose ontological status remains undecided as yet), but also incites us to revivify and rethink the notion of the concrete universal as such. Dialectically speaking, the synthetic cell emerges as a concrete instantiation of the current (technology-driven) conception of what life basically is. The notion of the "concrete universal" was introduced by Hegel in his Logic (1812/1986b, p. 298) but taken up by British Hegelians such as Francis Herbert Bradley (Stern 2007) and more recently by Žižek (2012/2013; cf. Kisner 2008). The concrete universal reflects Hegel's view on the time-old philosophical quandary concerning the relationship between general concepts (ideas) and concrete manifestations (between the transcendental and the empirical if you will). While the "cell" as a universal concept inevitably remains abstract and empty, concrete manifestations such as synthetic cells may be regarded as efforts of the idea to realise itself in a recognisable fashion, via technoscience. And the ultimate product of the BaSyC project will be a genuine synthetic cell insofar as its concrete reality will present a convincing realisation of the concept: insofar as it really is what it should be (Hegel 1830/1970a, § 213, pp. 368-369).

Yet, what is to be expected is that this end will be achieved in a finite manner, and will therefore be deficient more or less: so that the synthetic cell will be unable to completely live up to and concur with the concept (to fully realise the idea). From the point of view of the concept, all beings tend to be deficient beings, so that there is a positive result (realisation) and a negative result (negation, deficiency) at the same time. Žižek sees Hegel's concrete universal as the most radical expression of the "phantasy" that a reconciliation between the universal and the particular is achievable somehow, in the form of a concrete instantiation that allegedly fits its notion (Žižek 2012/2013, p. 357). This would validate the claim that technoscience becomes finally able to reproduce life in vitro (in a test-tube). In reality, there will always be a gap no doubt: a missing or deficient element that negates the universal concept, giving rise to the experience of "not yet" and fuelling further research. On the other hand, insofar as the concrete universal is indeed a recognisable manifestation of the universal concept, this particular understanding will inevitably taint and affect our understanding of life.

If we extrapolate these considerations to the synthetic cell project, it seems inevitable that the synthetic cell will somehow fall short and fail to realise our conception of life completely: a "negative" experience will always be involved, triggering additional, more radical research initiatives (as possible negations of this negation). On the other hand, insofar as the synthetic cell will be able to convincingly capture and materialise the concept of life on which it builds, our understanding of this concept will inevitably become affected by these laboratory experiences, for instance in the sense that these experiences will strengthen the bio-engineering, laboratory view of life that currently dominates contemporary life sciences research. 
Will the synthetic cell project indeed succeed in achieving its goal? Like all stations on the pathway towards knowledge it is to be expected that, similar to the HGP, the synthetic cell project will probably falter in the end, in the sense that its inherent contradictions and blind spots will be brought to the fore by the very research activities designed to demonstrate the validity of the concept. At the same time, we should avoid the excessive negativity that is conveyed by Žižek's conviction that, in the course of the dialectical knowledge process, the real loss of vitality (in our case: of the original living phenomenon) will only be supplemented by a "lifeless spectre" (Žižek 2012/2013, p. 197). This particular phrasing seems too "negative", in the dialectical sense of the term, because it suggests that technoscience is merely disruptive and that projects such as the synthetic cell project are bound to remain mere stubs. Dialectically speaking, it is rather to be expected that the failure will become apparent precisely because and insofar as the project's finite positive results will allow and force us to attain a higher level of understanding. Instead of pure spectral nothingness, the synthetic "something" produced in the course of the project will probably be convincing enough to act as a foil to generate supplementary research initiatives, building on this crucial "experience" (again: in the dialectical sense of the term): new research efforts to bridge the gap between the concept and the real. Even if it will not bring us the envisioned thing as such, the synthetic cell project will contribute to technoscientific selfreflection. Moreover, the sense of gap (Unangemessenheit) between concept (Begriff) and concrete existence (Existenz) also applies to natural entities. ${ }^{20}$

Whereas the negation (the second moment: $\mathrm{M}_{2}$ ) resulted in the disintegration of the object, the negation of the negation $\left(\mathrm{M}_{3}\right)$ cannot be expected to generate a truly "natural" cell (in the sense of a living organism), and this is the negative result. As a positive result, however, it may represent a crucial experience, for it may make us more aware of the ways in which we ourselves (as human subjects) are included in such projects: it will reveal the extent to which the synthetic cell conveys a technoscientific enframing of life. Whereas the first negation resulted in an obliteration of the object as we have seen, the synthetic cell project (as second negation, and as a reflexive appropriation of multiple partial components), will increase our understanding of what synthetic biology is and what its limits are: forcing us to reconsider the current relationship between technology and life, but also allowing us to develop a more comprehensive perspective, benefitting from this experience.

Again, this dialectical assessment not only helps us to position philosophy vis-à-vis technoscience, but also vis-à-vis empirical research. Although dialectics should familiarise itself with concrete research practices (with technoscience as a praxis, as something which is practiced), it would be a misunderstanding to see dialectics as empirical in the sense of sociological or ethnographical research. From an oblique perspective, neither the subject pole nor the object pole is regarded as empirical in the social scientific sense. The synthetic cell as a concrete entity (at the object pole of the process) emerges as the exemplification and realisation of an idea: the basic conviction that living nature as such (an sich) is basically a laboratory and that cells can only be really understood by rendering them techno-scientifically reproducible (in vitro). As to the subject pole, the research consortium (as an interdisciplinary research community) is not regarded as something empirical in the sociological or ethnographic sense, but as an exemplification and realisation of the holistic turn at the subject side of the process: synthetic biology as an interdisciplinary or even trans-disciplinary endeavour where the collaboration and conversion of multiple

\footnotetext{
20 "Alle endlichen Dinge haben eine Unwahrheit an sich, sie haben einen Begriff und eine Existenz, die aber ihrem Begriff unangemessen ist" (Hegel 1830/1970a, § 24, Zusatz p. 86).
} 
(partial and specialised) forms of technoscientific expertise is required in order to produce a comprehensive understanding of living systems on an elevated level of sophistication. The consortium and its program can be considered as a systematic technoscientific Summa of decades of life sciences research, incorporating various instances of partial knowledge based on past experiences. And again, our focus is on exploring and questioning the philosophemes, the basic convictions that guide this type of research.

Thus, a triadic dialectical unfolding can be discerned. The knowledge process begins with a general understanding of life and nature, a comprehensive world view: the first Moment $\left(\mathrm{M}_{1}\right)$ : the comprehension of something universal $(\mathrm{A})$, an abstract conceptual answer to the question "What is life?". Gradually, however, this hands-off constellation of thinking (contemplation) gives way to praxis, to specialisation and differentiation: to the emergence of specific disciplines and subdisciplines, focussing on very specific, particular aspects and partial objects (B), by research teams working in isolation from one another (dispersed across the campus): the second moment $\left(\mathrm{M}_{2}\right)$. The final inevitable step, however, is re-convergence: the emergence of trans-disciplinary knowledge fields such as molecular biology, genomics or synthetic biology, representing mutual interpenetrations of biology and computer sciences, quantum physics and genetics, environmental biology and computational biology, science and philosophy, etc. All these former specialisations now assemble around this concrete singular entity which is not yet visibly there, which has not yet arrived (so that the empty test-tube still stands out in waiting, as recipient and receptacle), but which already functions as a gathering point of orientation: the functional, self-sustaining and self-reproducing synthetic cell.

\section{The Synthetic Cell and the Anthropocene}

In the previous sections we have argued that the synthetic cell instantiates the current state of affairs in synthetic biology research: the dialectical development from universal conceptions of life (A), via analysis and obliteration (B), towards convergence (E). We may also see the synthetic cell against a broader synchronic backdrop, moreover, namely as a concrete exemplification of the current global condition: representing the Anthropocene as the end of modern history, a disruptive, transitory stage towards a new socio-technological constellation. The synthetic cell positions itself precisely at the turning point between natural (i.e. slow, gradual, incremental, Darwinian) evolution and a completely new chapter in the history of life and evolution, unleashed by technoscience, a new Cambrian explosion, ${ }^{21}$ currently raging in global laboratory networks (Church and Regis 2012) and which has already begun to spread throughout and infect the biosphere, bound to increasingly eclipse its natural, slow (Darwinian) precursor. The synthetic cell represents the "end of evolution" in the Hegelian sense of the term and the commencement of neo-life, evolving at a technological pace and on a different time scale. Whereas in the context of Darwinian (continuous) evolution significant changes required millions of years, neo-evolution evolves in a leap-like fashion, on a time-scale measurable in decades or even years.

Therefore, the synthetic cell urges us not only to take a step backward, but also a step forward in time. For dialectical epidemiologists, the synthetic cell project offers a window

\footnotetext{
21 During the Cambrian explosion, life on Earth, which until then had consisted mainly of (colonies of) single-cell organisms, diversified into a broad spectrum of novel life forms (Gould 1989).
} 
into an event of global significance, albeit flanked by a plethora of similar technoscientific developments of course, such as CRISPR-cas9 technologies for genome reediting. In its concreteness (Einzelheit), the synthetic cell project materializes and instantiates a development of wider significance: the technoscientific reproducibility and modifiability of life. Plasticity is now becoming an increasingly acute feature of living beings.

This process is understandable in terms of a dialectical unfolding. Initially (first moment, videtur, $\mathrm{M}_{1}$ ), human existence was experienced as embedded in nature, while the latter was considered as a cosmological whole. This must have applied to early human progenitors (who still existed as a natural species, in statu innocentiae as Thomas once phrased it), struggling to survive under natural conditions, now known as the Pleistocene and Holocene. Yet, a similar mood or experience of embedding can still be discerned during the agricultural era: the Common Human Pattern (Romein and Romein-Verschoor 1954), when the majority of humankind dwelled in self-sustaining villages and the idea still reigned that human existence should be regarded as inherently natural (secundam naturam) and as part of the natural scheme of things (Zwart 2009). The oeuvres of Aristotle and Thomas Aquinas can be regarded as supreme articulations of the philosophical superstructure of this extended era, which emerged during the Neolithic revolution and was negated by the industrial revolution. From that moment onwards, natural time gave way to clock-time and local life-worlds were eliminated and sublated by globalisation.

Yet, this philosophy of cosmological embeddedness and naturalness of the human condition was only one possible interpretation of the human situation. A different reading, a juxtaposed interpretation was possible already during the agricultural era (sed contra est), highlighting the negative and disruptive impact of human agricultural and artisanal practices. Via tool use and labour, notably since the Neolithic revolution, human societies had begun to produce clearings where new forms of experience became possible, resulting in a separation from nature (the second moment, $\mathrm{M}_{2}$ ), an experience which is conveyed by the phrase "man and nature", where the word and suggests a binary opposition between the human and the natural as we have seen. From this perspective, human culture (notably: agriculture) represents a moment of deviation and disruption: a negation of nature, of the natural way. Under these conditions, human technology in general and technoscience in particular are regarded as intrinsically disruptive.

This negativity was pushed to its extreme and became increasingly manifest after the onset of the industrial revolution, however, when human activity (notably due to massive exploitation and combustion of fossil fuels) became a meteorological and climatological factor, affecting the global atmosphere and biosphere. This looming crisis inevitably results in an important experience, however, namely that this separation between the human "and" the natural is misguided, and that we should rather see human existence in terms of mutual interpenetration of both opposites: the human and the natural, the technosphere and the biosphere (conclusio, $\mathrm{M}_{3}$ ). Insofar as we are developing a world of our own making, this inevitably has global environmental consequences, but also the reverse is true: to the extent that we are affecting the global environment, this will retroactively affect ourselves as well, as Engels already emphasises (1878/1962, p. $453 \mathrm{ff})$. This is precisely the meaning of the Anthropocene concept. Whereas fluctuations and perturbations during the Pleistocene and the Holocene could be conceived as resulting from purely natural meteorological and climatological dynamics, the term Anthropocene reflects the pervasive interpenetration of the natural and the human: of nature and technoscience. Indeed, Hegel himself already urges us to develop a comprehensive view by seeing planet Earth as a self-sustaining planetary process or system (Zwart 2017b). In other words, rather than seeing nature (the second part of Hegel's encyclopaedia) and culture (the third part) as separate realms, from a dialectical 
viewpoint we should see them as interpenetrating and converging. In the face of the current crisis we not only realise the disruptive impact of human technology on the natural environment, but also the retroactive impact of this disruption on human existence, as Engels already convincingly argued (1878/1962, p. 453 ff.).

How to position the synthetic cell against this backdrop? On the one hand the synthetic cell may be seen as a culmination of the technoscientific will to power, the drive to control nature, so that, should the project achieve its goals, it would be the ultimate assault on nature, resulting in a complete technification of nature. Starting from the living organism $\left(\mathrm{M}_{1}\right)$ which is systematically decomposed into its elementary components $\left(\mathrm{M}_{2}\right)$, the current trend is towards reconstitution and reparation, but on a higher level of modifiability and optimisation $\left(\mathrm{M}_{3}\right)$. At the same time, we may see the synthetic cell as an instantiation of a naturalisation of technology, a form of technoscience which takes the biological cell as its model $\left(\mathrm{M}_{1}\right)$ and, after decades of minute analysis $\left(\mathbf{M}_{2}\right)$, now tries to mimic it as truthfully as possible (Zwart 2019a, b). Potentially, at least, this could give rise to more advanced and optimised forms of technology $\left(\mathrm{M}_{3}\right)$, more sensitive to nature (Blok and Gremmen 2016) and striving towards concrete synthetic results.

We see this same dynamic reflected in the history of the philosophy of technology. The initial experience is articulated by Aristotle in Physics B (1980) where he explains that technology is a manner of shaping or moulding nature, in accordance with (and sensitive and responsive to) nature itself $\left(\mathrm{M}_{1}\right)$. Technology and nature are on a par. Yet, although Aristotle gives some interesting examples (such as constructing a bedstead while paying close attention to the natural features of the material, namely wood), he develops his reflections on a universal conceptual level (A). His aim is to define nature and technology as such. Real agricultural and artisanal interactions with nature (the experiences of labour) are outside the scope of his aristocratic worldview, and his contemplations are far removed from the mundane daily existence of menial toil and labour (Zwart 2009).

This evidently changes with the emergence of modern science, notably its applications in industry and agriculture $\left(\mathrm{M}_{2}\right)$. Inquiry now becomes a very active, hands-on and disruptive endeavour. Research becomes a technology-based praxis which requires both conceptual prowess and menial skill. ${ }^{22}$ By systematically exposing nature to particular circumstances and conditions, both in laboratories and in the field, specific physical, chemical, biological, etc. causal factors are studied (B) and nature becomes effectively modifiable.

At a certain point, however, this process of negativity and disruption will become pushed to such an extreme that it results in object loss. The negativity of technoscience is extrapolated into the real world, where nature is irreversibly violated, both inside and outside laboratories. As this process is pushed to its cataclysmic extreme, a new turning point seems inevitable. Post-millennial biotechnology will have to build on a different, more sensitive and sustainable way of being-in-the-world, and synthetic cell projects may exemplify this, as concrete instantiations (E) reflecting a whole new wave of concrete biotechnologies which aspire to reconcile nature and technology on a higher level of sophistication and comprehension, so that the final result is enriched by the cognitive process of differentiation and reintegration $\left(\mathrm{M}_{3} ; 1830 / 1970 \mathrm{a}, \S 215 \mathrm{Zusatz}\right.$, p. 373). Seen from this perspective, the synthetic cell may become part of a new wave of biocompatible biotechnologies and may contribute to the concrete realisation of the bio-mimicry concept (Blok and Gremmen 2016). Dialectically speaking, the Anthropocene crisis should be sublated into the noocene

22 "Lasst das Herumtreiben in leeren Abstraktionen, schaut auf eure Hände, erfasst das Hier, das Dieses, das Diesseits" (Hegel 1830/1970a, § 38 Zusatz, p. 109). 
(Zwart 2017b), i.e. the era of Nous or reason, transcending the inadequacies and biases of restricted, anthropocentric strategies (which sacrifice nature to short-term benefits of a particular species) to envision a second Achsenzeit (axial age), a dawning of geo-compatible and bio-compatible ways of being-in-the-world.

Acknowledgements This paper drew inspiration from various lectures and profited from discussions and responses: (a) "Extimate technologies and the conflict of the faculties during the noocene". Philosophy and Technology at the crossroads: Ihde-Stiegler Encounter. Nijmegen (The Netherlands): 11 January 2018; (b) "Building a synthetic cell: a philosophical assessment". BaSyC Consortium Symposium. Delft, 27 August 2018. (c) "From meta to beta and back: farewell lecture". Radboud University Nijmegen: 28 September 2018; (d) "What is Philosophy?" ESPhil Colloquium. Erasmus University Rotterdam: 23 January 2019.

This research is part of BaSyC, a gravitation project funded by the Netherlands Organisation for Scientific Research (NWO) (024.003.019)

Open Access This article is licensed under a Creative Commons Attribution 4.0 International License, which permits use, sharing, adaptation, distribution and reproduction in any medium or format, as long as you give appropriate credit to the original author(s) and the source, provide a link to the Creative Commons licence, and indicate if changes were made. The images or other third party material in this article are included in the article's Creative Commons licence, unless indicated otherwise in a credit line to the material. If material is not included in the article's Creative Commons licence and your intended use is not permitted by statutory regulation or exceeds the permitted use, you will need to obtain permission directly from the copyright holder. To view a copy of this licence, visit http://creativecommons.org/licenses/by/4.0/.

\section{References}

Aquinas, T. (1922). Summa Theologica. Taurini: Marietti.

Aristoteles. (1980). Physics. The Loeb classical library. Cambridge/London: Harvard University Press/ Heinemann.

Blok, V., \& Gremmen, B. (2016). Ecological innovation: Biomimicry as a new way of thinking and acting ecologically. Journal of Agricultural and Environmental Ethics, 29, 203-217. https://doi.org/10.1007/ s10806-015-9596-1.

Collins, F. (2011). The language of life. DNA and the revolution in personalised medicine. New York: Harper.

Church, G., \& Regis, E. (2012). Regenesis: How synthetic biology will reinvent nature and ourselves. New York: Basic Books.

Engels, F. (1878/1962). Herrn Eugen Dührings Umwälzung der Wissenschaft (Anti-Dühring). Marx Engels Werke XX (pp. 1-303). Berlin: Dietz Verlag.

Engels, F. (1886/1962). Ludwig Feuerbach und der Ausgang der klassischen deutschen Philosophie. Marx Engels Werke XXI (pp. 259-307). Berlin: Dietz Verlag.

Engels, F. (1925/1962). Dialektik der Natur. In: Marx Engels Werke XX (pp. 305-570). Berlin: Dietz Verlag.

Evans, D. (2008). The conflict of the faculties and the knowledge industry: Kant's diagnosis, in his time and ours. Philosophy, 83, 483-495. https://doi.org/10.1017/S0031819108000843.

Ferrini, C. (2011). The transition to organics: Hegel's idea of life. In S. Houlgate \& M. Bauer (Eds.), A companion to Hegel (pp. 203-224). Oxford: Blackwell.

Gould, S. J. (1989). Wonderful life: The Burgess Shale and the nature of history. New York: Norton.

Hegel, G. W. F. (1807/1973). Phänomenologie des Geistes. Werke 3. Frankfurt am Main: Suhrkamp.

Hegel, G. W. F. (1830/1970a). Enzyklopädie der philosophischen Wissenschaften I: Die Wissenschaft der Logik. Werke 8. Frankfurt: Suhrkamp

Hegel, G. W. F. (1830/1970b). Enzyklopädie der philosophischen Wissenschaften II: Die Naturphilosophie. Werke 9. Frankfurt: Suhrkamp.

Hegel, G. W. F. (1812/1986a) Wissenschaft der Logik I. Werke 5. Frankfurt: Suhrkamp.

Hegel, G.W.F. (1812/1986b) Wissenschaft der Logik II. Werke 6. Frankfurt: Suhrkamp.

Heidegger, M. (1951/1954). Das ding. In M. Heidegger (Ed.), Vorträge und Aufsätze (pp. 163-181). Pfullingen: Neske.

Hösle, V. (1987). Hegels System: der Idealismus der Subjektivität und das Problem der Intersubjektivität. Band 2: Philosophie der Natur und des Geistes. Meiner: Hamburg. 
Kant, I. (1798/2005). H. D. Brandt, P. Giordanetti (Eds.), Der Streit der Fakultäten. Hamburg: Felix Meiner. Kisner, W. (2008). The concrete universal in Žižek and Hegel. International Journal of Žižek Studies, 2(2), $1-38$.

Lemmens, P., \& Hui, Y. (2017). Reframing the technosphere: Peter Sloterdijk and Bernard Stiegler's anthropotechnological diagnoses of the anthropocene. Krisis: Journal of Contemporary Philosophy, 2, 26-41.

Levins, R., \& Lewontin, R. (1985). The dialectical biologist. Cambridge: Harvard University Press.

Malabou, C. (1996/2005). The future of Hegel: Plasticity, temporality and dialectic. London: Routledge.

Posch, T. (2011). Hegel and the sciences. In S. Houlgate \& M. Baur (Eds.), A companion to Hegel (pp. 177-202). Oxford: Blackwell.

Romein, J., \& Romein-Verschoor, A. (1954). Aera van Europa. Leiden: Brill.

Saks, V., Monge, C., \& Guzun, R. (2009). Philosophical basis and some historical aspects of systems biology: From Hegel to Noble: Applications for bioenergetic Research. International Journal of Molecular Sciences, 10, 1161-1192. https://doi.org/10.3390/ijms10031161.

Schrödinger, E. (1944/1967). What is life? The physical aspect of the living cell. London: Cambridge University Press.

Serres, M. (1972). Hermes II: L'interférence. Paris: Les Éditions de Minuit.

Stern, R. (2007). Hegel, British Idealism and the curious case of the concrete universal. British Journal for the History of Philosophy, 15(1), 115-153.

Žižek S. (2012/2013). Less than nothing: Hegel and the Shadow of dialectical materialism. London/New York: Verso.

Zwart, H. (2001). Tussen Euforie en Onbehagen: Geschiedenis en Toekomst van de Transplantatiegeneeskunde. Den Haag: Rathenau-Instituut.

Zwart, H. (2007). Genomics and self-knowledge. Implications for societal research and debate. New Genetics and Society, 26(2), 181-202.

Zwart, H. (2009). Biotechnology and naturalness in the genomics era: plotting a timetable for the biotechnology debate. Journal of Agricultural and Environmental Ethics, 22, 505-529.

Zwart, H. (2011). Francis Collins: The language of life. Book review. Genomics, Society and Policy, 6(3), $67-76$.

Zwart, H. (2012). On decoding and rewriting genomes: A Psychoanalytical reading of a scientific revolution. Medicine, Health Care and Philosophy, 15(3), 337-346.

Zwart, H. (2013). The genome as the biological unconscious - and the unconscious as the psychic 'genome': A philosophical rereading of molecular genetics. Cosmos and History: Journal of Natural and Social Philosophy, 9(2), 198-222.

Zwart, H. (2017a). The oblique perspective: Philosophical diagnostics of contemporary life sciences research. Life Sciences, Society \& Policy, 13, 4. https://doi.org/10.1186/s40504-017-0047-9.

Zwart, H. (2017b). From the Nadir of negativity towards the Cusp of reconciliation: A dialectical (HegelianTeilhardian) assessment of the anthropocenic challenge. Techné: Research in Philosophy and Technology, 21(2-3), 1-24. https://doi.org/10.5840/techne20176565.

Zwart, H. (2019a). Psychoanalysis of technoscience: Symbolisation and imagination. Series: Philosophy and psychology in dialogue. Berlin/Münster/Zürich: LIT Verlag. ISBN 978-3-643-91050-9.

Zwart, H. (2019b). From primal scenes to synthetic cells. eLife, 8, e46518. https://doi.org/10.7554/eLife .46518 .

Hub Zwart (1960) studied philosophy and psychology at Radboud University Nijmegen and defended his thesis in 1993. In 2000 he became full Professor of Philosophy at the Faculty of Science RU Nijmegen. In 2018 he was appointed as Dean of Erasmus School of Philosophy (Erasmus University Rotterdam). He published 15 books ( 5 in English) and $>100$ academic papers. He is editor-in-chief of the Library for Ethics and Applied Philosophy (Springer) and of the journal Life Sciences, Society and Policy (Springer). His research focusses on developing a dialectical assessment of contemporary technoscience. 